Terbit online pada laman : http://teknosi.fti.unand.ac.id/

Jurnal Nasional Teknologi dan Sistem Informasi

| ISSN (Print) 2460-3465 | ISSN (Online) 2476-8812

Studi Kasus

\title{
Konsep Pembaharuan Sistem Katalog Perpustakaan (Studi Kasus: Perpustakaan Universitas Di D.I Yogyakarta)
}

\author{
Khairul Fikri \\ Universitas Islam Indonesia, Jalan Kaliurang Km. 14.5, Yogyakarta, 55584, Indonesia
}

\section{INFORMASIARTIKEL}

Sejarah Artikel:

Diterima Redaksi: 20 Februari 2019

Revisi Akhir: 02 November 2020

Diterbitkan Online: 31 Desember 2020

\section{KATA KUNCI}

Perpustakaan

Katalog Buku

Integrasi

Linked data

e-katalog

KORESPONDENSI

E-mail: khairulfikri@students.uii.ac.id

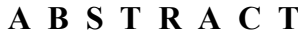

Saat ini berbagai perpustakaan sudah memiliki aplikasi/sistem katalog buku yang memudahkan pemustaka untuk mencari buku. Namun, karena kebutuhan pemustaka yang semakin bertambah maka perpustakaan harus menambah koleksi buku. Menambah koleksi membuat pembiayaan bertambah. Masalah muncul ketika stok buku sedikit, namun permintaan pemustaka sangat tinggi. Puncak permintaan terjadi saat akhir semester dimana banyak pemustaka yang butuh buku untuk ujian semester dan tugas akhir. Oleh sebab itu, penelitian ini bertujuan untuk memenuhi permintaan buku yang tinggi dari pemustaka. Peneliti melakukan action research yaitu memulai dengan survei ke beberapa perpustakaan untuk melihat aplikasi katalog. Membaca literatur untuk mengetahui perkembangan sistem katalog buku. Kuesioner di sebarkan untuk mengetahui perspektif pemustaka terhadap aplikasi katalog. Selanjutnya membuat rancangan atau desain sistem katalog buku perpustakaan berdasarkan perspektif pemustakan dan literatur yang dibaca. Sistem katalog perpustakaan saat ini (khususnya di wilayah D.I Yogyakarta dan Indonesia umumnya) sudah mulai mapan dan terintegrasi (antar fakultas). Hal ini bisa menjadi best practice bagi perpustakaan yang belum mapan. Pembaharuan tampilan dan layanan sesuai keinginan pemustaka dibutuhkan agar mereka tetap nyaman diperpustakaan. Konsep integrasi antar perpustakaan univeritas (bukan antar fakultas saja) memungkinkan pemenuhan kebutuhan pemustaka akan buku menjadi lebih besar. Linked data diharapkan bisa menjadi awal untuk memperkaya informasi katalog dan gerbang untuk memasuki era digitalisasi sehingga informasi dilihat melalui aplikasi (online), tidak lagi dengan kertas yang identik dengan fisik yang berat dan mudah rusak.

\section{PENDAHULUAN}

Perpustakaan menjadi gudang infomasi bagi banyak elemen masyarakat terutama bagi mahasiswa. Buku studi dan buku teori pendukung menjadi bahan bacaan mahasiswa untuk menunjang aktivitas perkuliahan mereka. Setiap buku disusun rapi dirak dan seiring pengunaan komputer maka muncul katalog koleksi buku secara digital. Katalog buku ini berbentuk sebuah sistem yang tertanam di sebuah komputer dengan fungsi untuk memudahkan pemustakamencari buku yang mereka inginkan.

Pencarian buku pada umumnya bisa berdasarkan judul buku atau nama penulis buku dan hasil pencarian berupa buku-buku yang terkait dengan kata kunci pencarian. Kelengkapan perpustakaan dalam nyediakan buku-buku menjadi salah satu yang bisa mempengaruhi katalog buku. Ketika koleksi buku sedikit maka hasil pencarian di sistem juga sedikit dan berkemungkinan tidak memiliki hasil pada sebagian pencarian yang dilakukan.

Koleksi buku menjadi penting di suatu perpustakaan, karena yang dicari oleh pemustakatidak lain yaitu buku atau bahan bacaan sejenisnya. Semakin banyak buku yang tersedia di perpustakaan maka semakin sering pemustakamengunjungi perpustakaan tersebut [1]. Selain koleksi buku, ada juga yang mempengaruhi pemustaka untuk mengunjungi perpustakaan atau meminjam buku yaitu tersedianya layanan e-jurnal, e-book, e-learning, peralihan bahan ajar, layanan internet, dan beberapa buku sudah dipinjam oleh pustakawan lain [2]. Tindakan yang dapat dilakukan untuk 
mengatasi tersebut salah satunya ialah memperkaya koleksi buku atau katalog buku.

Kenyataan yang terjadi pada perpustakaan yaitu buku yang ditambahakan oleh pustakawan masih ada yang tidak relevan dengan pemustaka, masih kurang koleksi buku terbaru, penempatan buku secara teknis masih berantakan sehingga sulit untuk ditemukan [3]. Selain itu dari segi sistem katalog buku perpustakaan sendiri masih baku dan kaku sehingga membuat pemustaka kurang tertarik untuk menggunakannya. Terdapatnya informasi yang hilang/tidak lengkap di sistem katalog seperti informasi foto buku, deskripsi buku, dan tidak sesuainya kondisi di sistem katalog dengan rak. Hal tersebut terjadi, karena tidak tervalidasi data yang ada di sistem katalog dengan kondisi buku di rak, misalnya ada buku yang hilang, dipinjam atau rusak [4].

Perbaikan koleksi buku perpustakaan dilakukan oleh pengelolah seperti penambahan buku dan penyesuaian buku yang muncul di katalog sesuai pemustaka yang menggunakan katalog. Hal ini bertujuan agar timbulnya rasa nyaman dalam mencari buku di katalog buku digital. Penyesuaian tersebut dapat dilihat dari jejak pemimjaman buku, profil pemustaka dan topik buku yang sering dibaca [5]. Sistem katalog buku menjadi penting untuk diperhatikan karena pemustaka akan lebih banyak berinteraksi dengan sistem tersebut sebelum mereka menemukan buku yang dicari.

Masalah muncul ketika stok buku sedikit, namun permintaan pemustaka sangat tinggi. Puncak permintaan terjadi saat akhir semester dimana banyak pemustaka yang butuh buku untuk ujian semester dan tugas akhir. Oleh sebab itu, penelitian ini bertujuan a) untuk memenuhi permintaan buku yang tinggi dari pemustaka, b) merancang sistem katalog perpustakaan terintegrasi, dan c) merancang antarmuka sistem katalog perpustakaan berbasis permintaan pemustaka.

Sistem katalog buku kaya informasi menjadi sasaran yang saat ini dirancang diberbagai tempat. Usulan menggunakan konsep agregator untuk memperkaya pengetahuan koleksi perpustakaan menjadi solusi, mengingat suatu perpustakaan harus menyediakan informasi yang mutakhir dan sesuai kebutuhan [6]. Linked data juga ada diusulkan sebagai bentuk untuk memperkaya pengetahuan tentang buku. Seperti informasi pengarang buku diambil dari dataset luar perpustakaan [7].Namun, kebutuhan informasi/pengetahuan tambahan tersebut perlu dilihat dari perspektif pemustaka. Hal-hal yang dilihat dapat berupa sikap penggunaan pemustaka terhadap sistem katalog, cara pemilihan buku, dan antarmuka sistem katalog yang di harapkan oleh pemustaka [8].

Integrasi antar perpustakaan menjadi salah satu solusi untuk memperkaya koleksi suatu perpustakaan. Misalnya perpustakaan X memiliki 1000 koleksi dan perpustakaan Y memiliki 1500 koleksi, maka totalnya menjadi 2500 koleksi. Ketika pemustaka di perpustakaan $\mathrm{X}$ mencari buku tertentu, bisa jadi buku tersebut tidak tersedia di perpustakaan $\mathrm{X}$ tetapi tersedia di perpustakaan $\mathrm{Y}$. Sejatinya satu perpustakaan tidak akan mampu mengakomodasi semua permintaan buku dari pemustakanya. Akan tetapi jika beberapa perpustakaan bergabung dalam melayani pemustaka, maka ada kemungkinan sebagian besar permintaan buku bisa terpenuhi. Konsep webservice menjadi salah satu pilihan untuk mewujudkan integrasi antar perpustakaan [9]. Selanjutnya perlu diperiksa apakah memang perlu dilakukan pembuatan seperti diatas dan seperti apa sistem katalog yang dibutuhkan oleh pemustaka.

Berdasarkan temuan diatas maka peneliti mengusulkan rancangan sistem katalog buku perpustakaan yang terintegrasi dengan katalog perpustakaan lain dan penambahan informasi dari dataset lain melalui linked data. Sehingga memunculkan pembaharuan baru pada persisteman katalog buku perpustakaan. Selain itu, juga ada penambahan lainnya berupa masukkan layanan dan tampilan baru yang muncul dari usulan pemustaka. Diharapkan sistem katalog tersebut bisa relevan dengan pemustaka, ketersediaan buku lebih besar, dan membantu pustakawan memberikan pelayanan yang lebih optimal.

Perpustakaan memiliki beberapa definisi yaitu buku dengan bahasa sansekerta-nya pustaka (di Indonesia menjadi perpustakaan yang menyatakan tempat). Sedangkan dalam bahasa Inggris disebut Library dan pada intinya semua mengatakan bahwa perpustakaan itu tempat tersedianya bahan bacaan seperti buku [1].

Sistem merupakan suatu kerangka kerja, prosedur, alur kegiatan, dan pendekatan yang disusun atau dikumpulkan untuk menyelesaikan satu atau beberapa masalah/sasaran yang telah ditentukan [5]. Secara bentuk atau fisiknya, sistem bisa lebih dari satu fisik atau aplikasi (jika berbasis perangkat lunak), tetapi semua itu saling berkaitan sehingga menjadi satu kesatuan yang disebut dengan sebuah sistem.

Katalog merupakan suatu istilah untuk daftar atau sekumpulan informasi yang disusun secara teratur [10]. Apabila dikaitkan dengan buku, maka menjadi sebuah definisi yang baru yaitu sekumpulan atau daftar-daftar buku yang disusun secara teratur. Penyusunan bisa berdasarkan judul buku, nomor buku, atau kelompok bidang ilmu dari buku tersebut.

Saat ini, katalog buku sudah berubah dari manual (catatan kertas) menjadi komputerisasi. Teknik penyusunan juga sudah bervariasi dan bisa menyesuaikan dengan kondisi pemustaka. Banyak peneliti yang telah membahas tentang katalog buku, khususunya diperpustakaan [1]-[3], [5], [7], [9], [11].

\section{Pada}

Tabel 1, dapat dilihat bahwa beberapa penelitian dan lembaga (pihak ketiga) sudah menerapkan/memberikan usulan beberapa fungsional seperi integrasi, linked data, dan panen data sehingga membuat sistem katalog perpustakaan menjadi lebih baik lagi. Berdasarkan hal tersebut, peneliti mencoba mengusulkan sistem katalog dengan rancangan yaitu:

1. Berdiri Sendiri 
Aplikasi bisa berjalan sendiri seperti sistem katalog pada umumnya, dengan kata lain tidak tergantung oleh sistem luar.

2. Sistem Pakar

Aplikasi memiliki sistem pakar seperti yang diusulkan oleh [5] yaitu sistem rekomendasi buku sesuai kepribadian pemustakan. Misalnya, buku sesuai jurusan universitas yang melekat pada pemustaka. Sistem rekomendasi bisa juga berdasarkan deksripsi buku seperti yang diterapkan oleh [12].

3. Validasi Data

Ini dibutuhkan agar informasi yang dikeluarkan oleh aplikasi katalog nantinya bisa valid sehinga sesuai dengan kenyataan dilapangan (dirak buku, misalnya) [4].

4. Integrasi

Aplikasi katalog buku dibangun dengan konsep integrasi antar perpustakaan universitas sehingga koleksi menjadi banyak [9], [13].
5. Linked Data

Linked data berfungsi untuk memperkaya informasi yang ada pada katalog buku perpustakaan [7].

6. Perspektif Pemustaka

Perspektif permustaka diambil sebagai tolak ukur nantinya bahwa yang dibangun sudah relevan dengan pemustaka [8].

7. Kotak Komentar

Kotak komentar disaran kan oleh pemustaka ketika kuesioner dibagikan oleh peneliti.

8. Usulan Buku

Sama sepeti poin ke tujuh, poin kedelapan ini merupakan saran dari pemustaka. Namun, peneliti [14] sudah pernah membahas ini untuk dimasukkan dalam sistem kartalog buku.

Tabel 1. Perbandingan Penelitian/Lembaga Perpustakaan.

\begin{tabular}{|c|c|c|c|c|c|c|c|c|c|c|}
\hline \multirow[t]{2}{*}{ No } & \multirow[t]{2}{*}{ Peneliti/Lembaga } & \multicolumn{7}{|c|}{ Teknis Aplikasi Katalog } & \multicolumn{2}{|c|}{ Tambahan } \\
\hline & & 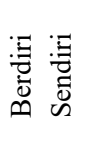 & 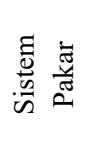 & 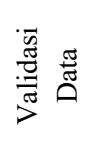 & 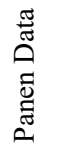 & 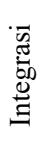 & 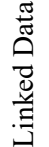 & 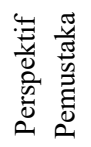 & 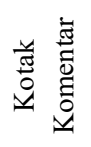 & $\frac{\text { ज्ञ }}{\overrightarrow{\vec{D}}} \frac{\vec{z}}{\vec{D}}$ \\
\hline
\end{tabular}

\begin{tabular}{lll}
\hline 1. & {$[9]$} & \\
\hline 2. & {$[5]$} & (Rekomendasi Buku) \\
& & \\
\hline
\end{tabular}

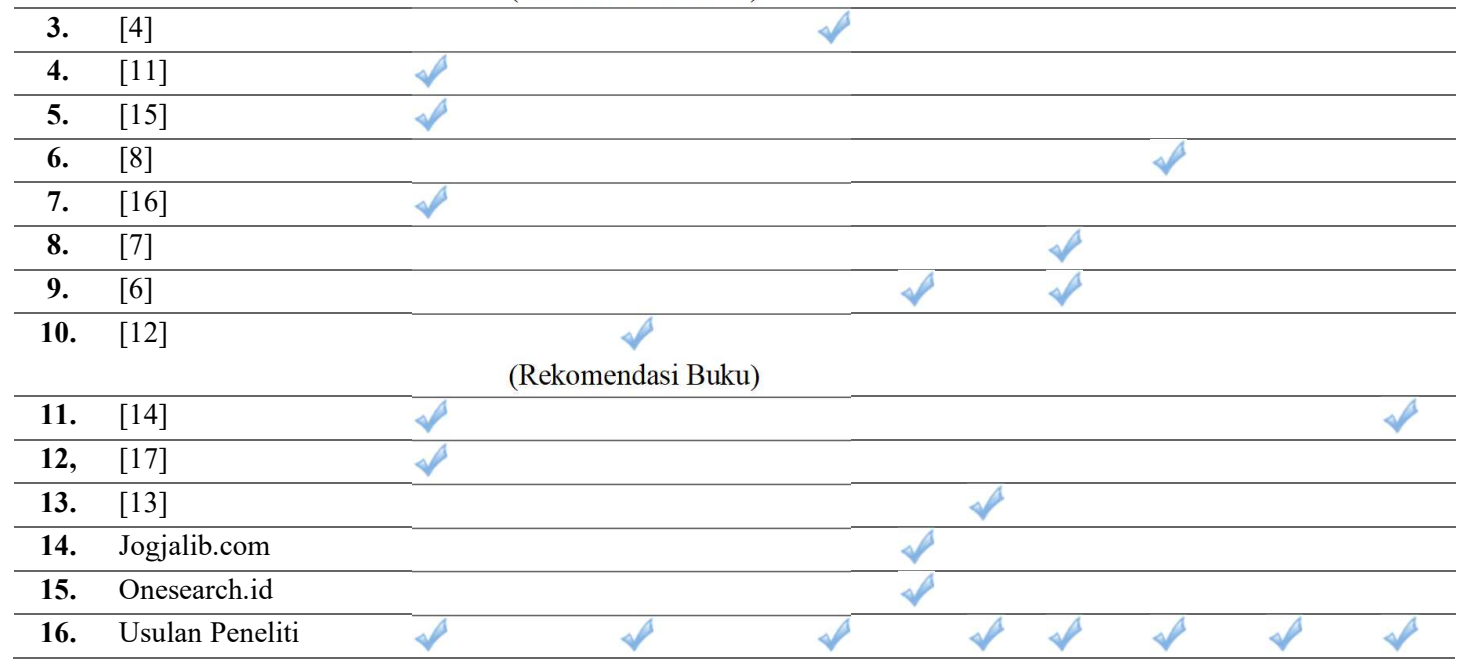

\section{METODE}

Peneliti mengadopsi dua tahap dari metode Action Research (AR) yang memiliki lima tahapan yaitu Diagnosis, Action Planning, Action Taking, Evaluation dan Learning [18]. Tahap yang digunakan pada penelitian ini yaitu Diagnosis dan Action Planning.
Tahap Diagnosis dilakukan survei ke beberapa perpustakaan untuk melihat aplikasi katalog. Membaca literatur untuk mengetahui perkembangan sistem katalog buku. Kuesioner di sebarkan untuk mengetahui perspektif pemustaka terhadap aplikasi katalog.

Tahap Action Planning berisi kegiatan membuat rancangan atau desain sistem katalog buku perpustakaan berdasarkan perspektif pemustakan dan literatur yang dibaca. 


\subsection{Pekembangan Sistem Katalog Buku Perpustakaan}

Katalog buku pada awalnya berupa buku catatan (manual) yang berisi sejumlah judul-judul buku berserta nomor rak buku. Seiring penggunaan komputer, pustakawan mulai menggunakan komputer untuk pembuatan label nomor buku dan selanjutnya pembuatan katalog digital berupa sistem informasi. Secara umum sistem yang dibangun mampu untuk mendata buku-buku yang masuk, data pemustaka dan pustakawan, transaksi peminjaman dan pengembalian buku, dan data koleksi buku [11].

Munculnya konsep integrasi data menyebabkan munculnya ide untuk mengintegrasikan data koleksi buku antar perpustakaan [9]. Kemudian disusul dengan konsep baru lagi yaitu pertukaran data bersifat bibliografi yang membuat setiap kata atau informasi memiliki sub informasi (detail) yang diperoleh dari dataset diluar sistem utama. Model ini disebut dengan linked data yang saat ini terdapat banyak dataset dibuka secara gratis seperti BBc programme, Geoname, Dbpedia.org, dan VIAF.org. [7].

Pemodelan sistem katalog buku perpustakaan berdasarkan perspektif pemustaka juga pernah dilakukan untuk melihat bagaimana pemustaka menggunakan sistem katalog, kebutuhan yang diperlukan oleh pemustaka, antarmuka yang diinginkan, dan informasi lebih (hasil linked data) yang diinginkan [8]. Namun, belum mencangkup mengenai integrasi antar perpustakaan dan layanan peminjaman antar perpustakaan. Oleh sebat itu, perlu dilihat lagi kebutuhan pemustaka terhadap katalog buku perpustakaan, apakah perlu pengintegrasian dan linked data? jika perlu, seperti apa yang dibutuhkan oleh pemustaka?

\subsection{Pengumpulan Data}

Data yang dikumpulkan pada penelitian ini melalui literatur review, observasi, dan kuesioner. Literatur review dilakukan untuk menemukan perkembangan dari topik penelitian, observasi dilakukan dibeberapa perpustakaan universitas yang ada di Kota Yogyakarta. Selanjutnya, kuesioner digunakan untuk mendapatkan data perspektif pemustaka tentang usulan integrasi dan linked data pada sistem katalog buku perpustakaan.

\subsection{Teknik Analisa}

Data yang telah dikumpulkan dari literatur review dan kuesioner pertama, akan di analisa sehingga menghasilkan suatu rancangan sistem katalog buku baru.

\section{HASIL DAN PEMBAHASAN}

\subsection{Kondisi Saat Ini dan Keinginan Pembaharuan}

Responden awal diambil dari 7 universitas yaitu A (5 responden), B (3 Responden), C (4 responden), D (18 responden), E (52 responden), F (1 responden), dan G (3 responden). Total awal respoden sebanyak 86 orang. Semua responden telah dipastikan bahwa pernah mengunjungi perpustakaan di Universitas masingmasing. Ada 80 responden yang pernah menggunakan katalog perpustakaan, 5 responden mengakui tidak pernah menggunakan katalog dan satu responden memilih untuk tidak menjawab.

Berhubung katalog perpustakan merupakan obyek penelitian, maka responden yang memenuhi syarat ialah 80 responden yang

https://doi.org/10.25077/TEKNOSI.v6i3.2020.116-128 pernah menggunakan katalog perpustakaan. Satu respoden dari 80 memilih untuk tidak menjawab pada salah satu pertanyaan kuesioner, sehingga responden tersedut tidak dimasukan untuk dianalisa. Selain itu juga ada satu responden yang berasal dari luar Kota Yogyakarta sehingga tidak dimasukkan. Total responden yang dijadikan bahan analisa adalah 78 orang.

Kosioner disebar secara online dan offline, Berdasarkan hasil yang didapatkan, ditemukan beberapa masalah pada aplikasi katalog, pemustaka dan perpustakaan. Sehingga, peneliti mengelompokkan hasil analisa kuesioner kedalam 4 bagian yaitu dihilangkan, dipertahankan, ditambah dan masalah.

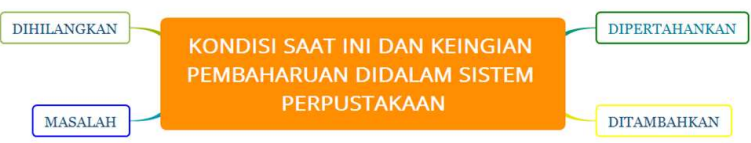

Gambar 1. Hasil Analisa Kuesioner - Empat Bagian Analisa.

Aplikasi katalog secara umum memiliki permasalah seperti segi informasi yang ditampilkan, ada beberapa masalah yaitu tidak ada deskripsi buku, tidak ada tahun terbit buku dan tidak ada gambar sampul buku. Informasi yang ditampilkan juga bermasalah mengenai kevalidatannya yaitu informasi status ketersediaan buku tidak sesuai dengan kondisi di rak buku, informasi nomor/kode buku tidak sesuai antara di katalog dengan yang ditempel dibuku, dan informasi lokasi buku tidak sesuai dengan kondisi di rak buku. Sebagian responden juga mengatakan bahwa tampilan katalog saat ini kurang menarik.

Aplikasi secara teknik juga bermasalah seperti aplikasi suka restart sendiri ke halaman awal pencarian, pencarian hanya terpaku pada judul buku sehingga menyebabkan hasil pencarian sedikit dan tidak bisa memberikan buku-buku yang terkait, selain itu pencarian tidak bisa dilakukan terhadap tema yang spesifik. Sebagian responden menyebutkan katalog di perpustakaan universitasnya terlalu rumit dalam hal pencarian.

Permasalahan dari segi pemustaka sendiri yaitu lupa judul buku, sulit mencari kata kunci, dan kesulitan saat pertama kali penggunaan. Sedangkan dari segi Perpustakaan itu sendiri, masalahnya yaitu adanya buku terselip antara satu buku dengan buku lainnya, beberapa komputer rusak sehingga tidak bisa digunakan, komputer sedikit juga menyebabkan antrian, internet lambat juga menyebabkan akses katalog bermasalah, buku yang tersedia sedikit khususnya mengenai tema tertentu seperti materi perkuliahan. Sebagian perpustakaan belum memiliki pengelompokkan rak buku berdasarkan ilmu pengetahuan (dapat dilihat padaLampiran - Gambar 11).

Ada beberapa hal yang harus dipertahankan dari sistem perpustakaan yang sudah berjalan saat ini yaitu dari segi aplikasi katalog, kemudaan yang didapat pemustaka dan perpustakaan itu sendiri. Namun, ada juga hal-hal yang berlum terpenuhi oleh perpustakaan dan hal tersebut dibutuhkan oleh pemustaka. Sehingga harus ada perubahan atau penambahan terhadap aplikasi katalog dan perpustakaan itu sendiri. Beberapa layanan atau fasilitas yang sudah ada, menurut pemustakan tidak diperlukan seperti pada aplikasi katalog terdapat informasi nama peminjam buku terakhir, buku yang terakhir dipinjam, dan peminjam yang terahir menyembalikan buku. Hal ini tentunya 
bisa dihilangkan jika memang pemustaka tidak membutuhkannya.

Hasil kuesioner mengungkapkan sebagian besar responden tertarik dengan ide integrasi antar perpustakaan universitas.

Perlu atau Tidaknya Integrasi antar Perpustakaan Universitas

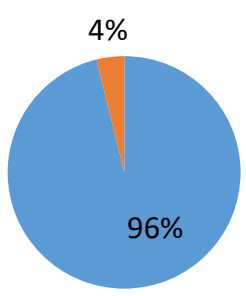

- Perlu

- Tidak Perlu

Gambar 2. Grafik respon responden terhadap ide integrasi antar perpustakaan universitas.

Sistem katalog buku kaya informasi menjadi sasaran yang saat ini dirancang diberbagai tempat. Usulan menggunakan konsep agregator untuk memperkaya pengetahuan koleksi perpustakaan menjadi topik penting, mengingat suatu perpustakaan harus menyediakan informasi yang mutakhir dan sesuai kebutuhan [6]. Linked data juga ada diusulkan sebagai bentuk untuk memperkaya pengetahuan tentang buku. Seperti informasi penulis diambil dari dataset luar perpustakaan [7]. Namun, kebutuhan informasi/pengetahuan tambahan tersebut perlu dilihat dari perspektif pemustaka. Hal-hal yang dilihat dapat berupa sikap penggunaan pemustaka terhadap sistem katalog, cara pemilihan buku, dan antarmuka sistem katalog yang di harapkan oleh pemustaka [8]. Tahap awal dilakukan terhadap 78 responden dan mereka sebagian besar menyetujui atau tertarik dengan konsep linked data untuk katalog perpustakaan (lihat Gambar 3).

Sistem katalog buku perpustakaan yang terintegrasi dengan katalog perpustakaan lain dan penambahan informasi dari data set lain melalui linked data memunculkan pembaharuan baru pada persisteman katalog buku perpustakaan. Selain itu, juga ada penambahan lainnya berupa masukkan layanan dan tampilan baru yang muncul dari usulan pemustaka. Sehingga sistem katalog tersebut bisa relevan dengan pemustaka, ketersediaan buku lebih besar, dan membantu pustakawan memberikan pelayanan yang lebih optimal.

\section{Perlu atau Tidaknya Informasi Katalog Diperkaya}

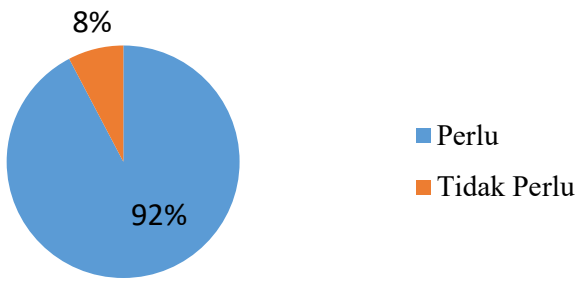

Gambar 3. Grafik respon responden terhadap ide linked data pada aplikasi katalog.

\subsection{Asal Usul Rancangan Sistem Katalog Perpustakaan}

Rancangan yang ingin dikemukakan yaitu tentang antarmuka dari sistem katalog berdasarkan perspektif pemustaka. Setidaknya ada empat tahapan yang akan dilalui oleh pemustaka dalam menggunakan katalog perpustakaan, yaitu:

1. Pertama, pemustaka membuka sistem katalog perpustakaan dan menggunakan kotak pencarian buku. Pemustaka memasukkan kata kunci untuk mencari buku.

2. Kedua, sistem katalog akan menampilkan hasil pencarian buku berupa list buku. Pemustaka memilih salah satu buku yang ingin dilihat.

3. Ketiga, sistem akan menampilkan halaman detail buku sesuai dengan pilihan pemustaka. Pada halaman detail buku akan terdapat beberapa kata/kalimat yang sudah memili hyperlink/tautan hasil dari linked data.

4. Keempat, pemustaka mengklik hyperlink/tautan pada detail buku untuk melihat informasi tambahan mengenai kata/kalimat yang diklik. Sistem akan menampilkan halaman baru yang berisi informasi tambahan (hasil dari linked data) dan hal ini seperti yang diusulkan oleh peneliti Prasetyo.

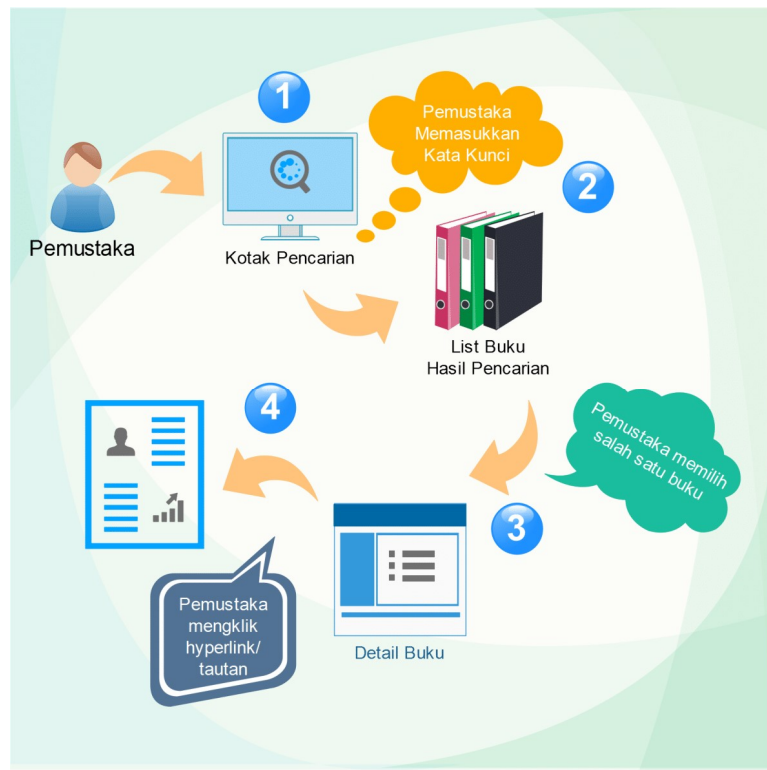

Gambar 4. Alur Pencarian Buku (Rancangan Usulan).

Selanjutnya, peneliti mengambil hasil penelitian dari [7]-[9] untuk membuat rancangan sistem katalog. Beberapa poin ada yang tidak diambil karena tidak memiliki nilai yang tinggi $(>50 \%$ responden) sehingga menjadi tolak ukur bahwa itu tidak diinginkan serta tidak dibutuhkan oleh pemustaka dalam menggunakan katalog buku perpustakaan. Peneliti juga menambahkan beberapa poin pada rancangan sistem katalog (peneliti telah memberikan kutipan pada masing-masing poin sesuai sumbernya).

\subsubsection{Usul Rancangan Kotak Pencarian}

Rancangan kotak pencarian didasari dari perilaku pemustaka dalam mencari buku dan standar fungsi pencarian pada umumnya. Pada umumnya, pencarian terfokus pada judul buku 
dan nama pengarang buku. Namun, kenyataanya pemustaka juga ingin mencari buku berdasarkan matakuliah yang sedang diambil/dipelajari. Hal tersebut dianggap agar nantinya hasil pencarian lebih relevan dengan keinginan buku yang dicari pemustaka.

Tabel 2. Teknik Pencarian Buku

\begin{tabular}{lll}
\hline Fungsi & \multicolumn{2}{l}{ Atribut / Keterangan } \\
\hline Pencarian berdasarkan & - & Judul Buku[8][9] \\
& - & Topik Buku[8] \\
& - & Nama Pengarang [8][9] \\
& - & Isi submateri buku. \\
& - & Keyword/Kata Kunci [9] \\
& - & Representasi Matakuliah [8] \\
& - & Bidang Ilmu. \\
& - & Jenis bahan bacaan, seperti \\
& & buku, skripsi, atau thesis. \\
& - & Instansi seperti perfakultas. \\
\hline
\end{tabular}

PadaGambar 5dapat dilihat bahwa untuk awalnya, pemustaka dihadapkan dengan kotak pencarian umum (pencarian berdasarkan judul buku). Namun, disediakan juga dibawahnya fasilitas pencarian lanjutan yang berisi metode pencarian berdasarkan topik buku, nama pengarang, isi buku/bacaan, kata kunci, jenis bacaan, dan representasi matakuliah/bidang ilmu. Setiap metode tidak perlu diisi sehingga bisa fokus satu metode pencarian saja.Secara teknis untuk metode pencarian bisa menggunakan metode Naive Bayes Clasifier seperti penelitian[19]-[21] atau menggunakan Algoritma Brute Force[22] agar hasil pencarian sesuai dengan topik yang dicari. Selain metode/algoritma diatas, masih ada dua algoritma lagi yaitu Algoritma Boyer Moore dan Algoritma Knuth Morris Pratt (KMP). Dari dua algoritma ini, Algoritma Boyer Moore dinyatakan sebagai algoritma yang tercepat dalam melakukan pencarian[23].

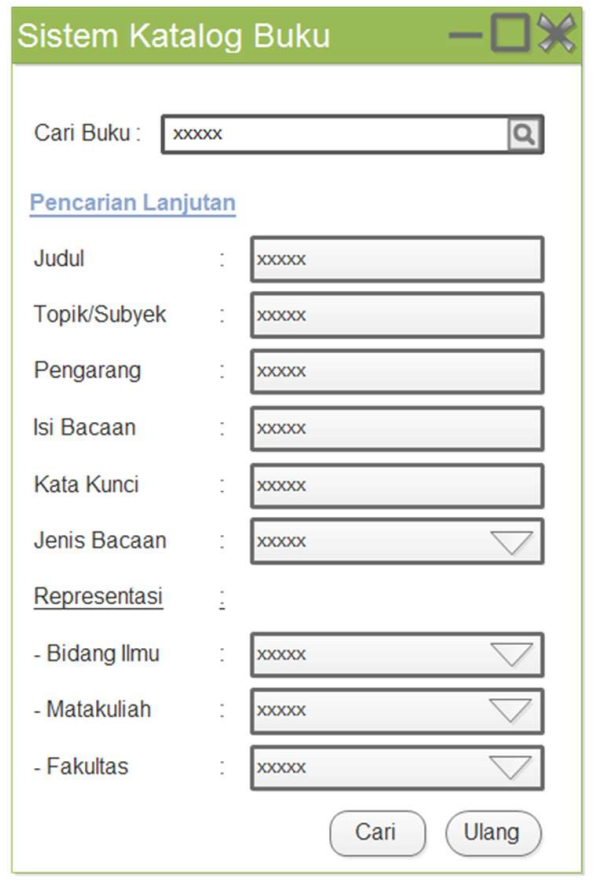

Gambar 5. Rancangan Antarmuka Halaman Kotak Pencarian Buku.

\subsubsection{Usul Rancangan Tampilan List Buku Hasil Pencarian}

Pada tampilan awal yaitu hasil pencarian dari katalog buku, sebaiknya menampilkan komponen/atribut yang penting-penting saja atau yang menjadi tolak ukur pemustaka dalam memilih buku. Berdasarkan dua penelitian sebelumnya dan kuesioner, didapatlah sembilan atribut utama yang harus ditampilan di halaman hasil pencarian katalog.

Pemustaka mengklik judul buku(lihat Gambar 6) untuk melihat detail dari buku dan nomor halaman hasil pencarian disediakan apabila hasil pencariannya banyak. Asumsi yang diterapkan bisa seperti hasil pencarian perhalaman hanya 10 buku saja, untuk melihat hasil pencarian yang ke 11-20 maka bisa klik tombol nomor halaman (Misalnya tombol 2 atau 3 ).

Tabel 3. Informasi Yang Ditampilkan Pada Halaman List Buku Hasil Pencarian.

\begin{tabular}{ll}
\hline Atribut List Buku & Keterangan \\
\hline Cover Buku & {$[8]$} \\
\hline Deskripsi Isi Buku & {$[8]$} \\
\cline { 2 - 2 } & Penjelasan buku. \\
\cline { 2 - 2 } & Sinopsis buku. \\
\hline Judul Buku & {$[8][9]$} \\
\hline Klasifikasi atau Jenis & Klasfikasi bahan bacaan atau \\
Buku/Bahan Bacaan. & jenis bacaan seperti Buku, \\
& Thesis, Makalah dan lainnya \\
& yang sejenis. [8] \\
\hline Lokasi Buku & {$[8][9]$} \\
\hline Nama Pengarang & {$[8][9]$} \\
\hline Nama Penerbit & {$[8][9]$} \\
\hline Tahun Terbit & {$[8]$} \\
\hline Topik/Subyek Buku & Topik (subyek) dari buku. [8] \\
\hline
\end{tabular}

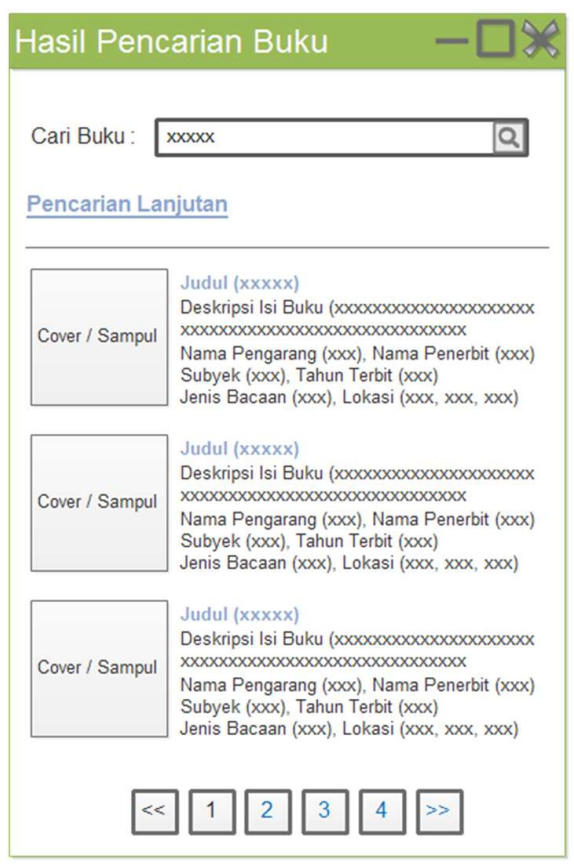

Gambar 6. Rancangan Antarmuka Halaman List Buku Hasil Pencarian. 


\subsubsection{Usul Rancangan Tampilan Detail Buku}

Beberapa poin dari hasil kuesioner tidak dimasukkan karena beberapa poin bertentangan dengan poin lainnya seperti sebagian responden mengatakan butuh poin $\mathrm{A}$, tetapi ada responden lain yang mengatakan tidak butuh poin A. Untuk hal ini peneliti menetapkan bahwa yang lebih banyak respoden mengatakan butuh/tidak akan menjadi keputusan akhir (dimasukkan/tidaknya). Rancangan tampilan detail buku (lihat Gambar 8) diambil dari penelitian [7], [8] dengan penyesuaian berdasarkan hasil data kuesioner penelitian ini.

Tabel 4. Informasi Pada Halaman Detail Buku

\begin{tabular}{|c|c|}
\hline Atribut Detail Buku & Keterangan \\
\hline Cover Buku & [8] \\
\hline Buku-buku setopik/subyek & [8] \\
\hline Buku-buku terkait penerbit & [8] \\
\hline Buku-buku terkait penulis & [8] \\
\hline Daftar Isi Buku & [8] \\
\hline Deskripsi Isi Buku & [8] \\
\hline ISBN & - \\
\hline Judul Buku & [8] \\
\hline Jumlah Buku & Jumlah total exemplar \\
\hline Jumlah Halaman Buku & - \\
\hline Kata Kunci Buku & - \\
\hline Ketersediaan Buku & $\begin{array}{l}\text { Jumlah buku yang tersedia } \\
\text { dirak. }\end{array}$ \\
\hline $\begin{array}{l}\text { Klasifikasi atau Jenis } \\
\text { Buku/Bahan Bacaan. }\end{array}$ & $\begin{array}{l}\text { Klasfikasi bahan atau jenis } \\
\text { bacaan seperti Buku, Thesis, } \\
\text { Makalah dan lainnya yang } \\
\text { sejenis. [8] }\end{array}$ \\
\hline Kode Buku & $\begin{array}{l}\text { Kode buku atau kode panggil } \\
\text { buku atau DDC. }\end{array}$ \\
\hline Kota Terbit & - \\
\hline \multirow[t]{4}{*}{ Lokasi Buku } & $\begin{array}{lr}\text { Lokasi buku } & \text { (rak, } \\
\text { perpustakaan). }[8] & \end{array}$ \\
\hline & Nomor Rak Buku \\
\hline & $\begin{array}{l}\text { Nomor lantai gedung letak } \\
\text { buku. }\end{array}$ \\
\hline & $\begin{array}{l}\text { Letak buku model } 3 \text { dimensi } \\
\text { (opsional) }\end{array}$ \\
\hline Nama Pengarang & [8] \\
\hline Nama Penerbit & {$[8]$} \\
\hline Nomor Cetakan Buku & - \\
\hline Topik/Subyek Buku & $\begin{array}{l}\text { Topik (subyek) dari buku. } \\
\text { [8] }\end{array}$ \\
\hline Tahun Terbit & [8] \\
\hline
\end{tabular}

\subsubsection{Usul Rekomendasi Pengadaan Buku Baru}

Pada penelitian sebelumnya dan kuesioner, terungkap bahwa ada beberapa keingin pemustakan terhadap buku seperti ingin buku terbitan baru, buku yang terkenal (best seller) dan buku yang sedang dibutuh untuk keperluan tertentu. Hal tersebut menjadi landasan bagi pemustakawan dalam menetapkan buku apa saja yang akan di beli atau ditambah.
Tabel 5. Rekomendasi bagi pustakawan dalam Pengadaan Buku Baru

\begin{tabular}{ll}
\hline Atribut & Keterangan \\
\hline Edisi Terbaru & $\begin{array}{l}\text { Edisi terbaru dari buku yang } \\
\text { pengarangnya terpercaya.[8] }\end{array}$ \\
\cline { 2 - 2 } & Buku terbitan baru. \\
\hline Request Pemustaka & $\begin{array}{l}\text { Pemustaka memberikan } \\
\text { rekomendasi buku-buku } \\
\text { kepada pemustakawan untuk } \\
\text { dibeli. Ini senada dengan } \\
\text { penelitian [14]. }\end{array}$ \\
\hline Buku luar negeri & $\begin{array}{l}\text { Buku luar negeri yang } \\
\text { terjemahan bahasa Indonesia. }\end{array}$ \\
\hline Buku best seller & \\
\hline Buku materi perkuliahan & $\begin{array}{l}\text { Buku-buku terkait matakuliah } \\
\text { yang ada di Universitas. }\end{array}$ \\
\hline
\end{tabular}

\subsubsection{Usul Rekomendasi Layanan Baru Pada Sistem Katalog}

Saat menganalisa hasil kuesioner, peneliti menemukan beberapa saran dari pemustaka terkait layanan tambahan pada sistem katalog.

Tabel 6. Rekomendasi Layanan Baru Pada Sistem Katalog

\begin{tabular}{ll}
\hline Fungsi & Atribut / Keterangan \\
\hline Penampil/viewer & $\begin{array}{l}\text { Penampil PDF terkhusus untuk } \\
\text { jurnal, skripsi, dan thesis. }\end{array}$ \\
\hline Kotak Komentar & $\begin{array}{l}\text { Kolom komentar untuk } \\
\text { pemustaka. }\end{array}$ \\
\hline $\begin{array}{l}\text { Peminjaman Antar } \\
\text { Perpustakaan }\end{array}$ & $\begin{array}{l}\text { Peminjaman buku milik } \\
\text { perpustakaan yang berbeda } \\
\text { (misal Universitas B) bisa } \\
\text { dilakukan melalui perpustakaan } \\
\text { Universitas pemustaka } \\
\text { (misalnya Universitas A) tanpa } \\
\text { harus datang ke universitss B. }\end{array}$ \\
\hline
\end{tabular}

\subsection{Konsep Integrasi Antar Perpustakaan}

Konsep integrasi menggunakan webservice diusulkan oleh Kristiani. Pada Gambar 7 terlihat bahwa kedua database perpustakaan saling dihubungkan dengan perantara. Sehingga kedua sistem katalog bisa saling berbagi data walaupun data berada di masing-masing universitas yang jauh jaraknya. Hal ini juga pernah dilakukan oleh [13] pada perpustakaan kota Semarang dan daerah Jawa Tengah ( menggunakan metode RESTful) 


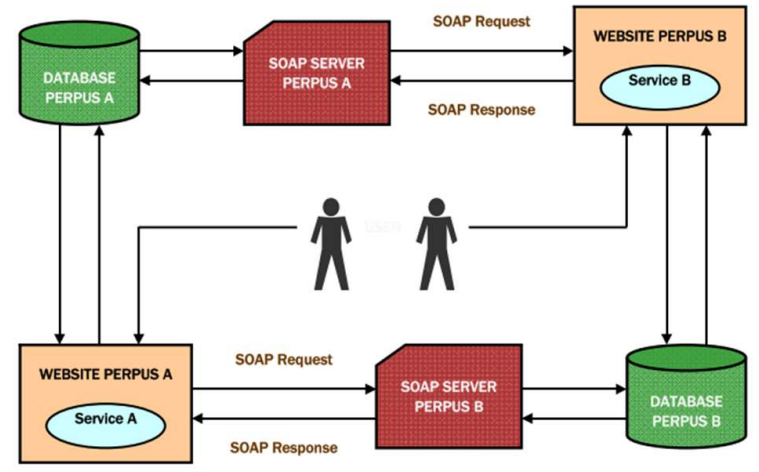

Gambar 7. Contoh Integrasi Katalog dengan Webservice[9].

Berikut ini kelebihan konsep integrasi dengan webservice (Gatner Inc. dalam [24]:
1. Database bisa berada pada masing-masing universitas.

2. Kedua database tetap terhubung walaupun masingmasing memakai jenis/provider database yang berbeda.

3. Berdiri sendiri dan tidak tergantung dengan yang lain sehingga jika sistem katalog A down/bermasalah maka sistem katalog B tetap jalan.

4. Bisa mendukung bahasa pemrograman apapun.

5. Pertukaran data mudah dilakukan antar anggota (yang mau berintegrasi).

6. Webservice lebih unggul dari pada Application Programming Interface (API) karena bisa diakses jarak jauh (via internet).

7. Webservice memiliki kemampuan untuk layanan timbal balik sesuai permintaan (yang me-request).

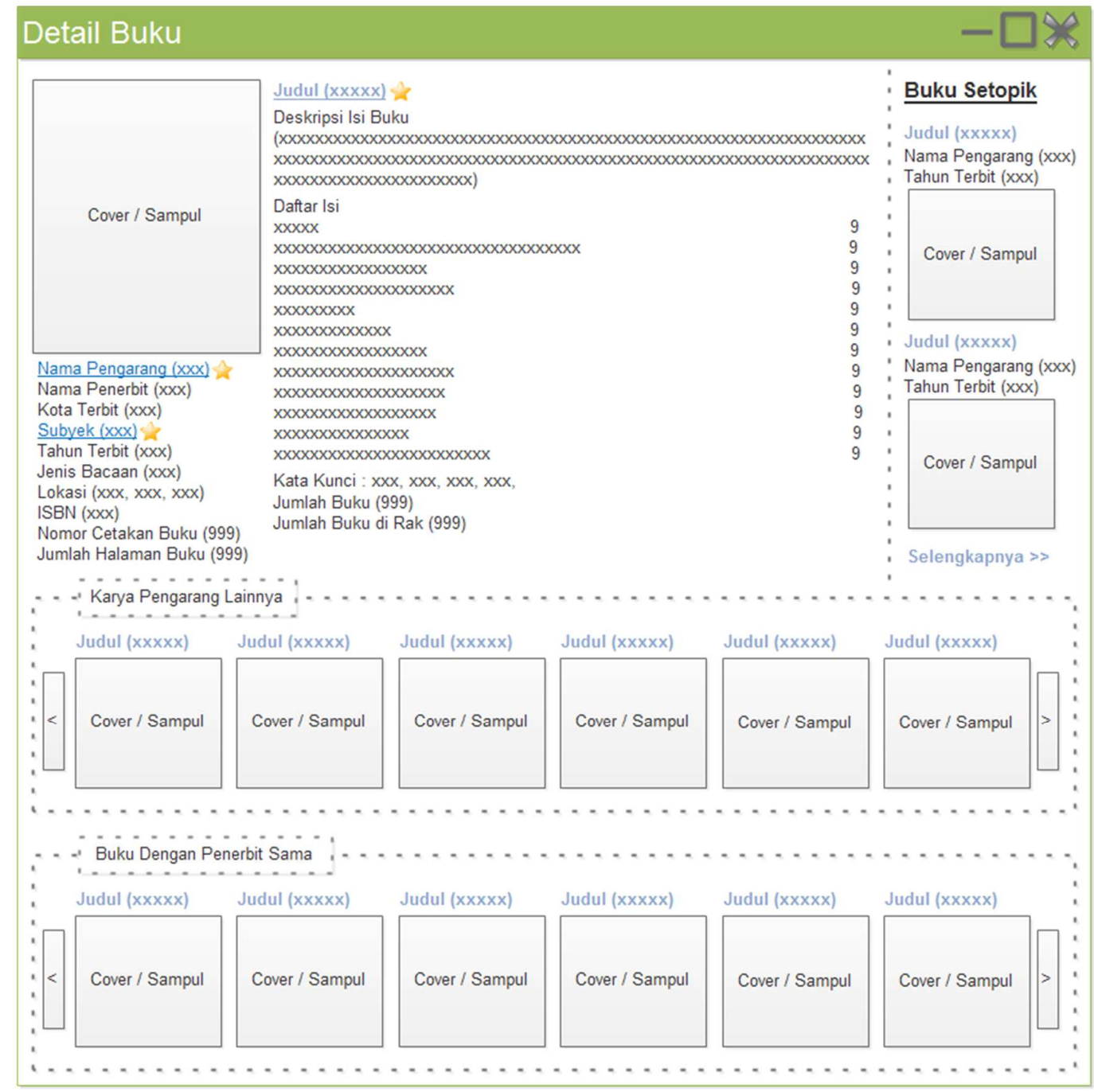

Gambar 8. Rancangan Antarmuka Halaman Detail Buku.

Saat ini telah ada beberapa pihak atau lembaga yang telah mencoba melakukan integrasi antar database katalog perpustakaan, seperti:

\section{Onesearch.id}

https://doi.org/10.25077/TEKNOSI.v6i3.2020.116-128
Indonesia One Search (IOS) merupakan sebuah website $e$ resource yang mengumpulkan database katalog buku, database arsip, database mesium yang ada di seluruh Indonesia (khususnya bagi lembaga yang sudah bergabung dengan IOS). Layanan ini dibuat oleh team Perpustakaan Nasional RI dan Islmail Fahmi merupakan inisiatornya. Metode yang digunakan 
yaitu metode harvesting. Semua data diambil dari repositori online milik lembaga yang sudah bergabung menjadi anggota IOS. Tentuya setiap anggota diwajibkan membuat API agar Onesearch bisa mengambil data katalog buku perpustakaan anggota[25].

\section{Jogjalib.com}

Jogjalib merupakan aplikasi yang dibuat oleh Dinas Perpustakaan Dan Arsip Daerah provinsi D.I Yogyakarta tahun 2005. Tujuan utama yaitu memudahkan pemustaka dalam mencari buku baik itu di perpustakaan sekolah/universtias atau perpustakaan lembaga pemerintah. Layanan Silang Pinjam menjadi nilai tambah utama bagi Jogjalib, karena dengan layanan ini para pemustaka dapat meminjam buku diperpustakaan yang berbeda (syaratnya perpustakaan pemustaka dan perpustakaan tempat buku yang dipinjam sudah menjadi anggota layanan Silang Pinjam)[26].

Pada Gambar 12 (lihat halaman lampiran) terdapat tiga contoh yang peneliti ambil untuk konsep integrasi. Pada IOS teknik pengambilan data disetiap sistem katalog perpustakaan mensyaratkan untuk membuat API agar IOS bisa mengambil data. Ruang lingkup pengambilan sangat luas yaitu seluruh Indonesia. Berbeda dengan JogjaLibrary, ruang lingkupnya untuk satu provinsi saja yaitu D.I Yogyakarta. Namun, saat ini peneliti belum mendapatkan informasi lengkap mengenai metode secara teknis integrasi yang digunakan JogjaLibrary. Berdasarkan informasi yang disampaikan pada laman resmi Jogjalib.com, peneliti melihat dan menyimpulkan bahwa teknik pengumpulan data JogjaLibrary hampir sama dengan IOS, namun berkemungkinan integrasinya seperti yang diusulkan peneliti[9]. Hal tersebut dikarenakan pada JogjLibrary terdapat layanan SilangPinjam sehingga peneliti beranggapan bahwa JogjaLibray tidak hanya memanen data dari setiap perpustakaan tetapi juga integrasi yang sebenarnya (yaitu dua arah). Atau kemungkinan lainnya yaitu tidak terjadi integrasi secara teknik namun hanya sekedar perjanjian bahwa anggota perpustakaan yang termasuk di Silang Pinjam bisa meminjam buku di perpustakaan berbeda tanpa harus mendaftar lagi (membuat kartu anggota perpustakaan).

\subsection{Konsep Linked Data pada Sistem Katalog Buku}

Konsep linked data sebenarnya bertujuan untuk memperkaya informasi dari suatu informasi awal. Misalnya:

$\begin{array}{ll}\text { Judul buku } & \text { : Analisis Sistem Informasi } \\ \text { Penulis } & \text { : Tata Sutabri } \\ \text { Penerbit } & \text { : Andi }\end{array}$

Jika kita coba perkaya informasinya, maka hasilnya berupa artikel/informasi menganai apa itu sistem?, Definisi sistem?, Contoh sistem?, Bagaimana pengertian kata informasi?, dan Sejarah Sistem Informasi?. Peneliti pecaya masih banyak dan bisa dikembangkan lagi informasi mengenai judul tersebut.

Mewujudkan munculnya informasi tambahan dari judul tersebut bisa dilakukan dengan konsep menghubungkan setiap kata dari judul dengan suatu dataset informasi yang relevan. Sebagai contoh sederhana, peneliti membuat 3 kelompok dataset seperti pada Gambar 9. Jika kita menghubungkan judul buku (contoh 124 Khairul Fikri diatas) dengan ketiga kelompok dataset tersebut, maka akan muncul informasi yang berkesinambungan.

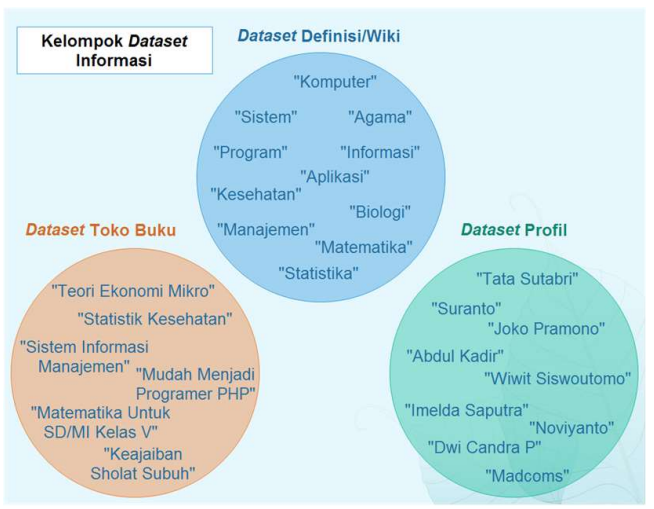

Gambar 9. Kelompok Dataset Informasi.

Contoh:

Kata "Sistem" pada judul buku bisa diterus ke dataset definisi/wiki sehingga muncullah informasi pengertian dari kata "Sistem". Selanjutnya dihubungkan ke dataset Toko Buku sehingga muncul informasi tentang buku-buku yang terkait atau membahas tentang kata "Sistem". Terakhir jika dihubungkan ke dataset Profil maka muncul informasi siapa yang pernah menulis atau membahas tentang kata "Sistem". Penghubungan dataset tidak hanya satu arah tetapi juga bisa duarah dan langsung melihatkan beberapa dataset sekaligus.

Linked data diterapkan untuk memperkaya informasi pada katalog, seperti yang diusulkan oleh Prasetyo terhadap aplikasi SliMS. SliMS atau Senayan Library Management System merupakan aplikasi yang dibuat oleh sebuah tim menggunakan bahasa pemrograman PHP. Tim tersebut berasal dari Pusat Informasi dan Humas Departemen Pendidikan Nasional Republik Indonesia. SliMS ini digunakan untuk aplikasi perpustakaan seperti halnya sistem katalog perpustakaan. Prasetro dan kawankawan mengusulkan untuk halaman detail buku (dari hasil pencarian oleh pemustaka di sistem katalog) diperlus informasinya melalui linked data. Informasi yang hendak di perkaya ialah data judul, data author, dan data subyek seperti pada Gambar 8 bagian yang diberi tanda bintang ( $)$.

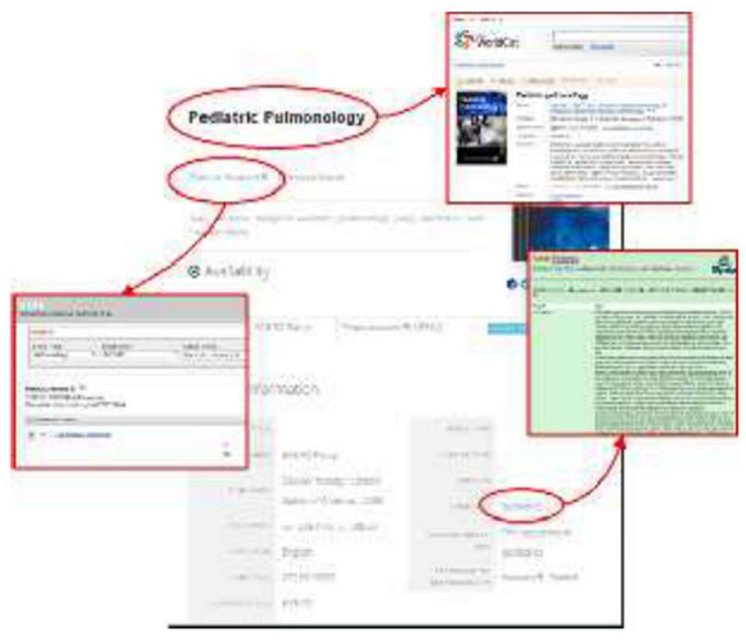

Gambar 10. Contoh Usulan Linked data pada aplikasi SliMS[7]. https://doi.org/10.25077/TEKNOSI.v6i3.2020.116-128 


\subsection{Buku Digital Masa Depan}

Sebagian besar perpustakaan yang diteliti telah mencoba memasuki digitalisasi bahan bacaan, khususnya karya tulis ilmiah yaitu jurnal, prosiding, skripsi, dan tesis. Namun, untuk skripsi dan tesis biasanya hanya tersedia secara offline sehingga pemustaka harus datang ke perpustakaan menggunakan komputer khusus.

Saat ini, belum ada perpindahan buku fisik/hardcopy menjadi buku digital di perpustakaan. Namun, diluar perpustakaan sudah mulai ada pembuatan buku dalam bentuk digital. Salah satu media atau alat untuk membuat buku digital yaitu Kvisoft FlipBook Maker [27].

\section{KESIMPULAN}

Penelitian ini bertujuan untuk membuka wawasan tentang pembaharuan sistem katalog buku perpustakaan. Selain itu dapat disimpulkan bahwa perangcangan sebuah sistem harus memperhatikan perspektif dari user/pengguna sistem dengan tujuan mengahasilkan sistem yang relevan dan bisa digunakan oleh pengguna. Akhir dari penelitian ialah sebuah best practice untuk pembuatan ataun perbaikan sistem katalog buku perpustakaan. Rancangan pembaharuan sistem katalog buku perpustakaan telah peneliti sampaikan pada bab sebelumnya dan diharapkan bisa membantu sistem katalog buku perpustakaan di Universitas wilayah Indonesia.

\section{DAFTAR PUSTAKA}

[1] N. Jamaluddin, "Pengaruh Ketersediaan Koleksi Terhadap Kunjungan Pemustaka di Perpustakaan Universitas Muhammadiyah Makassar," Universitas Islam Negeri Alauddin, 2017.

[2] Maryono et al., "Faktor Yang Berpengaruh Pada Penurunan Jumlah Peminjaman Buku Di Perpustakaan UGM Periode 2003-2007: Penelitian Pendahuluan," Forum Pustakawan UGM, 2015.

[3] V. E. Ohoiwutun, D. M. D. Warouw, and M. Turang, "Pengaruh Manajemen Koleksi Perpustakaan Terhadap Minat Baca Mahasiswa Jurusan Ilmu Keperawatan Universitas Katolik De La Salle Manado,” Acta Diurna, vol. III, no. 2, 2014.

[4] T. Supanti, J. Sapatri, and F. Marpaung, "Validasi Data Katalog Perpustakaan PUSPAR UGM," Berk. Ilmu Perpust. dan Inf., vol. IX, no. 2, pp. 32-43, 2013.

[5] P. R. Hasibuan, A. S. Honggowibowo, and H. Wintolo, "Sistem Pakar Rekomendasi Peminjaman Buku Di Perpustakaan Sekolah Tinggi Teknologi Adisutjipto Yogyakarta Dengan Metode Penyaringan Kolaboratif," Compiler, vol. 1, no. 1, 2012.

[6] D. F. Saputra, "Agregator Sebagai Alat Pengembangan Koleksi Perpustakaan Berbasis Website," Pustakaloka, vol. 8, no. 2, pp. 201-210, 2016.

[7] E. B. Prasetyo, Hendrik, and R. T. Dirgahayu, "Model Bibliografi Berbasis Linked Data Pada Perpustakaan Digital," in Seminar Nasional Teknologi Informasi dan Multimedia, 2016, pp. 6-7.

[8] B. Susanto and U. Proboyekti, "Pemodelan Data Berbasis Semantic Web Untuk Katalog Buku Perpustakaan Universitas," in Seminar Hasil Penelitian dan Pengabdian pada Masyarakat, 2015, no. November.
E. Kristiani, "Pemanfaatan Teknologi Web Services Pada Pertukaran Data Katalog Antar Perpustakaan," Tek. dan Ilmu Komput., vol. 01, no. 02, pp. 208-220, 2012.

[10] KBBI, "Kamus Besar Bahasa Indonesia (KBBI)," KBBI Daring KEMDIKBUD, 2016. .

[11] F. Nugraha, "Analisa dan Perancangan Sistem Informasi Perpustakaan,” J. SIMETRIS, vol. 5, no. 1, pp. 27-32, 2014.

[12] R. F. Oeyliawan and D. Gunawan, "Aplikasi Rekomendasi Buku Pada Katalog Perpustakaan Universitas Multimedia Nusantara Menggunakan Vector Space Model," J. Ultim., vol. 9, no. 2, pp. 97105, 2017.

[13] E. R. Subhiyakto, Y. P. Astuti, and N. K. Ningrum, "Pengembangan Aplikasi Katalog Perpustakaan Terintegrasi Menggunakan Metode RESTful pada Perpustakaan Kota Semarang dan Perpustakaan Daerah Jawa Tengah," J. Inform. J. Pengemb. IT, vol. 03, no. 02, pp. 161-166, 2018

[14] A. Jubaedah and S. Rahayu, "Pengembangan Aplikasi Katalog Online Berbasis Web di Perpustakaan SMAN 26 Garut," J. Algoritm., vol. 14, no. 2, pp. 74-80, 2017.

[15] S. Mulyati, R. Hidayat, and I. D. Lestari, "Rancang Bangun Sistem Informasi Transaksi Peminjaman Buku Berbasis WEB Online pada Perpustakaan Universitas Muhammadiyah Tangerang," J. Tek., vol. 4, no. 2, pp. 34-39, 2015.

[16] D. Linda, "Merancang e-katalog Berbasis Website Sebagai Media Informasi pada Badan Perpustakaan Arsip dan Dokumentasi Daerah (BPAD) Lampung Deppi," Explor. - J. Sist. Inf. dan Telemat., vol. 6, no. 2, pp. 167-180, 2016.

[17] H. Miftahul, B. E. Purnama, and Sukadi, "Rancang Bangun Katalog Buku Online Pada Perpustakaan Umum Daerah Kabupaten Pacitan," Indones. J. Netw. Secur., pp. 1-6, 2018.

[18] A. Zakiah, A. Ekawijana, and E. A. Laksana, "Implementasi Metode Action Research untuk Peningkatan Daya Saing Umkm Melalui E-Commerce," J. Penelit. Komun. Dan Opini Publik, vol. 23, no. 1, 2019.

[19] A. Setiawan, I. Fitri Astuti, and A. Harsa Kridalaksana, "Klasifikasi Dan Pencarian Buku Referensi Akademik Menggunakan Metode Naïve Bayes Classifier (NBC) (Studi Kasus: Perpustakaan Daerah Provinsi Kalimantan Timur)," J. Inform. Mulawarman, vol. 10, no. 1, 2015.

[20] A. P. Kusuma and I. Srirahayu, "SISTEM PENCARIAN KATALOG BUKU MENGGUNAKAN METODE NAIVE BAYES CLASIFIER (NBC) PADA APLIKASI MULIA-BOOKSTORE BERBASIS ANDROID," $J$ Antivirus, vol. 10, no. 2, pp. 50-55, 2016.

[21] F. Handayani, "Sistem Penunjang Keputusan Pencarian Katalog Buku Menggunakan Metode Naive Bayes Pada Perpustakaan STIE SURAKARTA," STMIK Sinar Nusantara Surakarta, 2017.

[22] T. Zebua and N. Silalahi, "Aplikasi Saran Buku Bacaan Bagi Pengunjung Perpustakaan AMIK STIEKOM Sumatera Utara Berdasarkan Algoritma Brute Force," $J$. Ris. Sist. Inf. Dan Tek. Inform., vol. 3, pp. 66-72, 2018.

[23] A. Fau, Mesran, and G. L. Ginting, "Analisa Perbandingan Boyer Moore Dan Knuth Morris Pratt Dalam Pencarian Judul Buku Menerapkan Metode Perbandingan Eksponensial ( Studi Kasus: Perpustakaan STMIK Budi Darma )," J. Times (Technology Informatics Comput. Syst., vol. 6, no. 1, pp. 12-22, 2017.

[24] R. E. Putra, B. M. Izzati, and F. Dewi, "Optimasi Kinerja Point Of Sale (POS) Dengan Penerapan Sinkronisasi Database Menggunakan Middleware," Inform. 
Mulawarman J. Ilm. Ilmu Komput., vol. 12, no. 2, p. 123, 2017.

[25] I. Fahmi, "Indonesia OneSearch Empowering Discovery and Innovation," Jakarta, 2016.

[26] P. Sudaryanto, "Liputan Khusus Tentang Jogjalib.com," DPAD D.I Yogyakarta, 2015.

[27] D. G. H. Divayana, P. W. A. Suyasa, and A. Adiarta, "Pelatihan Pembuatan Buku Digital Berbasis Kvisoft

\section{LAMPIRAN}

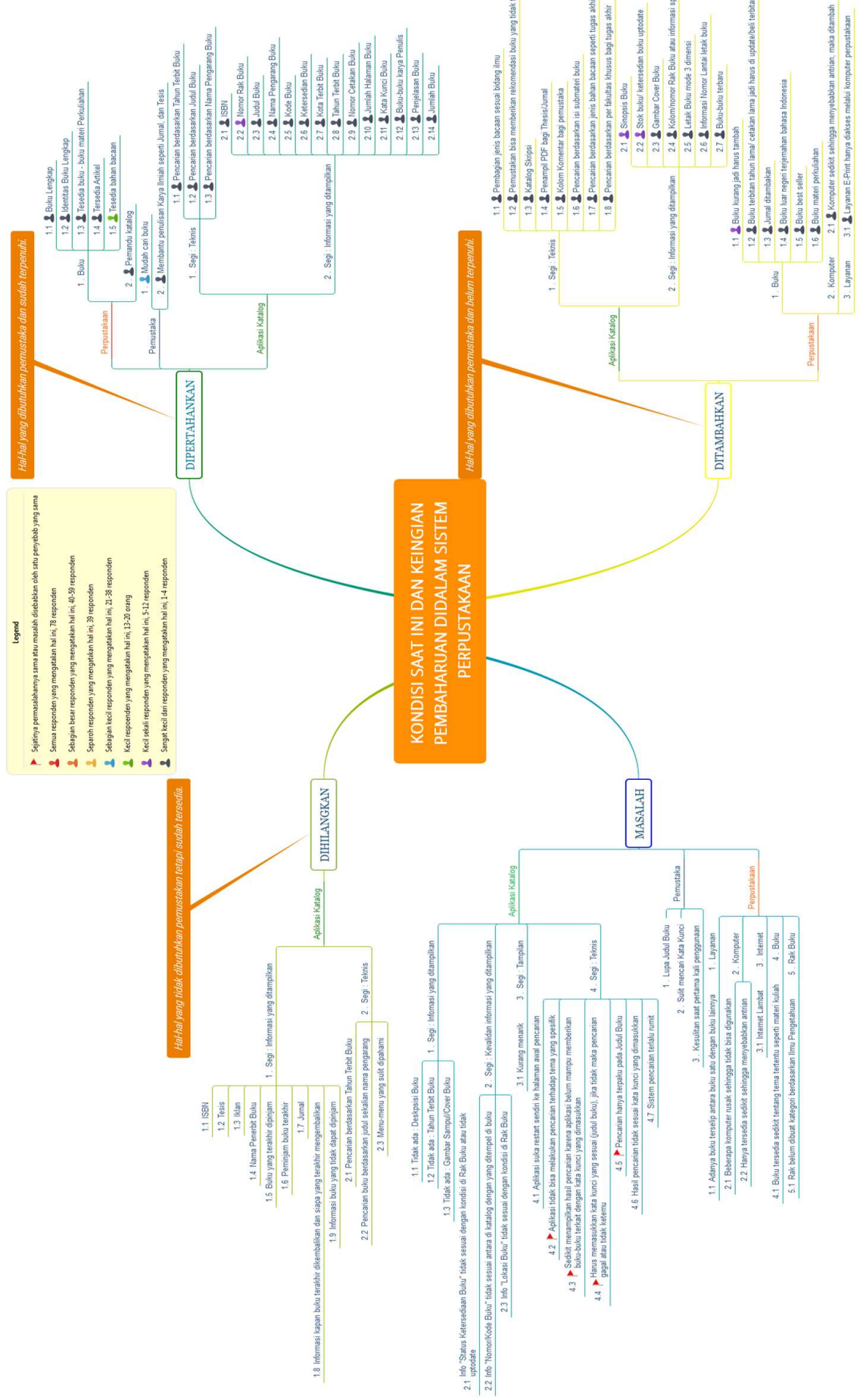

Gambar 11. Hasil Analisa Kouesioner. 


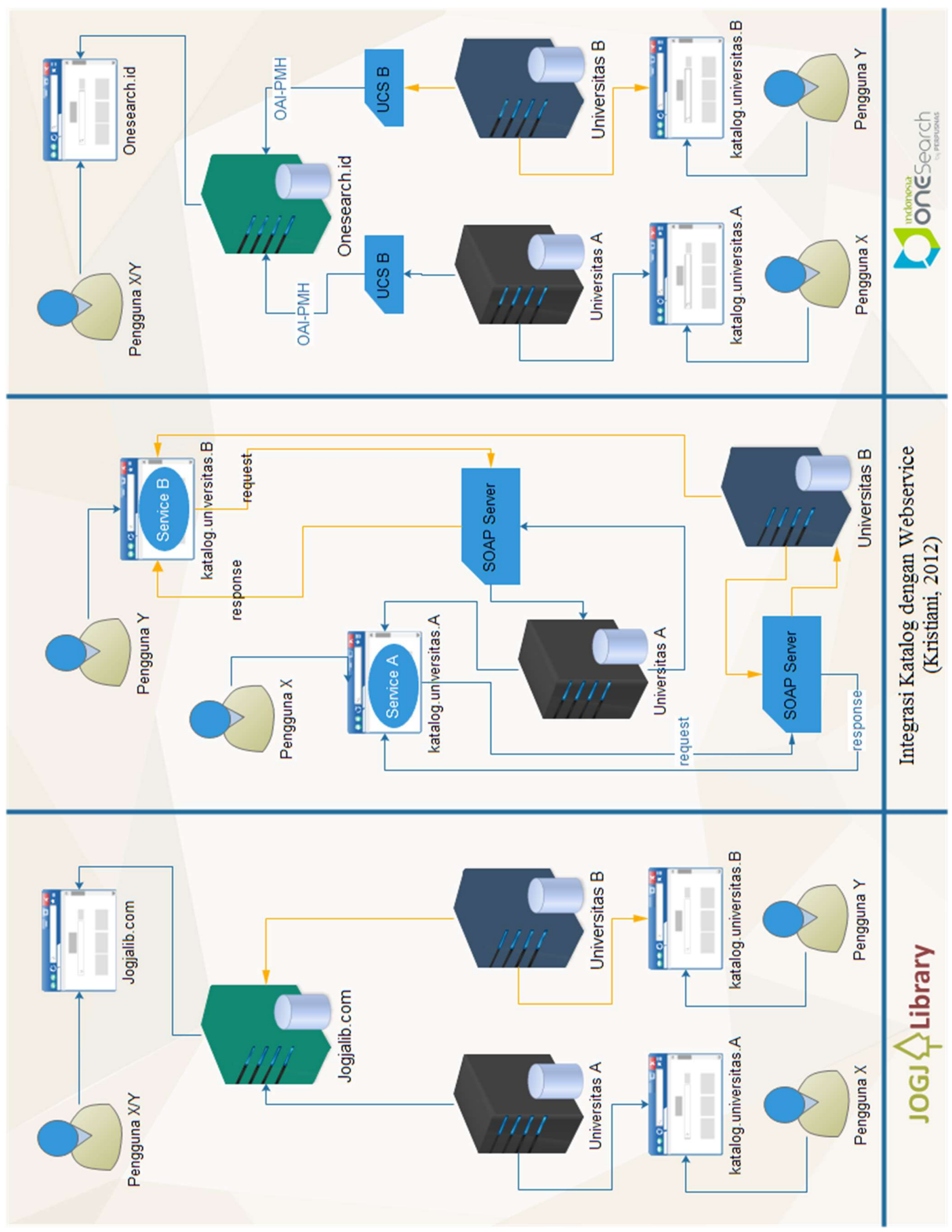

Gambar 12. Perbedaan Motode Integrasi Antar Perpustakaan (3 contoh kasus). 
Tabel 7. Pertanyaan Kuesioner untuk Pemustaka.

\begin{tabular}{|c|c|c|}
\hline No & Pertanyaan & Jawaban Yang Tersedia \\
\hline 1. & Apakah Anda pernah mengunjungi Perpustakaan Universitas? & $\square$ Pernah $\square$ Tidak Pernah \\
\hline 2. & Dalam rentang satu minggu, berapa kali Anda mengunjungi Perpustakaan? & $\begin{array}{l}\square \text { Sekali } \square \text { Dua kali } \square \text { Kurang dari } 5 \text { kali } \\
\square \text { Kurang dari } 10 \text { kali } \square \text { Lebih dari } 10 \text { kali }\end{array}$ \\
\hline 3. & Apakah Anda pernah menggunakan Katalog Perpustakaan Universitas? & $\square$ Pernah $\square$ Tidak Pernah \\
\hline 4. & $\begin{array}{l}\text { Dari } 10 \text { kali kunjungan Perpustakaan, berapa kali Anda menggunakan } \\
\text { Katalog Perpustakaan? }\end{array}$ & $\begin{array}{l}\square 1 \square 2 \square 3 \quad \square 4 \square 5 \\
\square 6 \quad \square 7 \square 8 \square 9 \square 10\end{array}$ \\
\hline 5. & Berapa lama Anda menggunakan Katalog untuk mencari Buku? & $\begin{array}{l}\square \text { 1-5 menit } \square \text { 5-10 menit } \square \text { 10-15 menit } \\
\square \text { 15-20 menit } \square \text { Lebih dari } 20 \text { menit }\end{array}$ \\
\hline 6. & $\begin{array}{l}\text { Apakah Anda mengakses Katalog melalui komputer yang disediakan pihak } \\
\text { Perpustakaan? }\end{array}$ & $\square$ Ya $\square$ Tidak. \\
\hline 7. & $\begin{array}{l}\text { Dari keempat media dibawah ini, manakah yang sering Anda gunakan untuk } \\
\text { mengakses Katalog Perpustakaan? }\end{array}$ & $\begin{array}{l}\square \text { Komputer sendiri } \square \text { Laptop sendiri } \\
\square \text { Smartphone sendiri } \\
\square \text { Komputer Perpustakaan Universitas }\end{array}$ \\
\hline 8. & Lebih sering mana, cari buku melalui Katalog atau langsung di rak buku? & $\begin{array}{l}\square \text { Cari buku melalui Katalog Perpustakaan } \\
\square \text { Langsung di rak buku }\end{array}$ \\
\hline 9. & Apa kesulitan yang Anda alami dari menggunakan Katalog Perpustakaan? & Responden isi sendiri \\
\hline 10. & Apa saran Anda terhadap aplikasi Katalog Perpustakaan yang ada? & Responden isi sendiri \\
\hline 11. & $\begin{array}{l}\text { Dari beberapa bahan bacaan dibawah ini, manakah yang sering Anda cari } \\
\text { diperpustakaan melalui aplikasi Katalog? }\end{array}$ & $\begin{array}{l}\square \text { Buku } \square \text { Makalah } \quad \square \text { Artikel } \\
\square \text { Tugas Akhir } \square \text { Skripsi } \square \text { Thesis }\end{array}$ \\
\hline 12. & Apa alasan Anda mencari buku di Perpustakaan? & $\begin{array}{l}\square \text { Tugas dari perkuliahan } \\
\square \text { Mengisi waktu senggang/kosong } \\
\square \text { Ingin menambah pengetahuan atau } \\
\text { wawasan } \\
\square \text { Lainnya:__responden_isi_sendiri }\end{array}$ \\
\hline 13. & Apakah Anda pernah meminjam buku Perpustakaan? & $\square$ Pernah $\square$ Tidak pernah \\
\hline 14. & $\begin{array}{l}\text { Setelah buku yang dicari telah didatkan, apakah Anda membacanya di } \\
\text { Perpustakaan atau membacanya dirumah? }\end{array}$ & $\begin{array}{l}\square \text { Lebih sering membaca di Perpustakaan } \\
\text { tanpa membawa pulang. } \\
\square \text { Lebih sering membaca dirumah. }\end{array}$ \\
\hline 15. & Hal apa saja Anda butuhkan dan sudah terpenuhi di Katalog tersebut? & Responden isi sendiri \\
\hline 16. & $\begin{array}{l}\text { Hal apa saja yang belum terpenuhi oleh Katalog Perpustakaan Universitas } \\
\text { saat ini? }\end{array}$ & Responden isi sendiri \\
\hline 17. & $\begin{array}{l}\text { Pada aplikasi Katalog saat ini, apa saja yang tidak Anda butuhkan tetapi } \\
\text { tersedia di katalog? }\end{array}$ & Responden isi sendiri \\
\hline 18. & $\begin{array}{l}\text { Pada umumnya perpustakaan di Universitas Yogyakarta sudah memiliki } \\
\text { aplikasi Katalog Buku. Ada sebuah usulan yang bertujuan untuk } \\
\text { mengintegrasikan/menghubungkan antar perpustakaan yang ada. Sehingga } \\
\text { jika buku yang dicari tidak tersedia di Universitasnya maka aplikasi katalog } \\
\text { bisa mencari buku tersebut di Universitas lain. Kemudian, aplikasi akan } \\
\text { menampilkan bahwa buku tersedia di Universitas lain tersebut dan bisa } \\
\text { meminjam melalui Universitasnya secara langsung. Menurut Anda apakah } \\
\text { hal ini (integrasi antar perpustakaan Universitas) perlu dilakukan? }\end{array}$ & $\begin{array}{l}\square \text { Perlu } \\
\square \text { Tidak perlu } \\
\square \text { Lainnya:__responden_isi_sendiri }\end{array}$ \\
\hline 19. & $\begin{array}{l}\text { Linked data membuat informasi Katalog buku menjadi kaya akan informasi } \\
\text { seperti subyek buku dikaitkan dengan dataset/informasi diluar perpustakaan } \\
\text { misalnya Dpedia.org. Harl tersebut akan menghasilkan informasi tambahan } \\
\text { mengenai subyek buku tersebut (yaitu definisi, sejarah, dan lainnya). } \\
\text { Contohnya, subyek buku = Statistika. Maka hasil informasi: berupa } \\
\text { informasi pengertian, sejarah, konsep, metode, dan lainnya yang sama } \\
\text { seperti Anda melihat halaman: https://id.wikipedia.org/wiki/Statistika. } \\
\text { Menurut Anda, apakah informasi di katalog perpustakaan perlu di perkaya } \\
\text { dengan informasi tambahan? }\end{array}$ & $\begin{array}{l}\square \text { Perlu } \\
\square \text { Tidak perlu } \\
\square \text { Lainnya:__responden_isi_sendiri }\end{array}$ \\
\hline
\end{tabular}

